\title{
Unraveling Sources and Climate Conditions Prevailing during the Deposition of Neoproterozoic Evaporites Using Coupled Chemistry and Boron Isotope Compositions $\left(\delta^{11} \mathrm{~B}\right)$ : The Example of the Salt Range, Punjab, Pakistan
}

\author{
Syed Asim Hussain ${ }^{1,2,3,4, *}$, Feng-Qing Han ${ }^{1,2,3, *}$, Zhe Ma $^{1,2,3}$, Amjad Hussain ${ }^{5}$, Muhammad Saleem Mughal ${ }^{6}$, \\ Jibin Han ${ }^{1,2,3}$, Abdullah Alhassan ${ }^{7}$ (i) and David Widory ${ }^{8}$ (D)
}

1 Key Laboratory of Comprehensive and Highly Efficient Utilization of Salt Lake Resources, Qinghai Institute of Salt Lakes, Chinese Academy of Science, Xining 810008, China; mazhe@isl.ac.cn (Z.M.); jbhan@isl.ac.cn (J.H.)

2 Qinghai Provincial Key Laboratory of Geology and Environment of Salt Lakes, Xining 810008, China

3 University of Chinese Academy of Sciences, Beijing 100049, China

4 Department of Earth Sciences, Karakoram International University, Gilgit, Gilgit-Baltistan 15100, Pakistan

5 State Key Laboratory of Geological Processes and Mineral Resources, China University of Geosciences, Wuhan 430074, China; amjad.khoshhall@gmail.com

check for updates

Citation: Hussain, S.A.; Han, F.-Q.; Ma, Z.; Hussain, A.; Mughal, M.S.; Han, J.; Alhassan, A.; Widory, D. Unraveling Sources and Climate Conditions Prevailing during the Deposition of Neoproterozoic Evaporites Using Coupled Chemistry and Boron Isotope Compositions $\left(\delta^{11} \mathrm{~B}\right)$ : The Example of the Salt Range, Punjab, Pakistan. Minerals 2021, 11, 161. https://doi.org/10.3390/ $\min 11020161$

Academic Editor:

Krzysztof Bukowski

Received: 30 December 2020

Accepted: 29 January 2021

Published: 3 February 2021

Publisher's Note: MDPI stays neutral with regard to jurisdictional claims in published maps and institutional affiliations.

Copyright: (c) 2021 by the authors. Licensee MDPI, Basel, Switzerland. This article is an open access article distributed under the terms and conditions of the Creative Commons Attribution (CC BY) license (https:/ / creativecommons.org/licenses/by/ $4.0 /)$.
6 Institute of Geology, University of Azad Jammu and Kashmir Muzaffarabad, Azad Jammu and Kashmir 13100, Pakistan; saleem.mughal@ajku.edu.pk

7 State Key Laboratory of Biogeology and Environmental Geology, China University of Geosciences, Wuhan 430078, China; abdullah@cug.edu.cn

8 GEOTOP/Earth and Atmosphere Sciences Department, UQAM, Montréal, QC H3C 3P8, Canada; widory.david@uqam.ca

* Correspondence: s.asim_110@yahoo.com (S.A.H.); hanfq@isl.ac.cn (F.-Q.H.)

\begin{abstract}
In this study, the ion concentrations $\left(\mathrm{K}^{+}, \mathrm{Na}^{+}, \mathrm{Ca}^{2+}, \mathrm{Mg}^{2+}, \mathrm{Cl}^{-}, \mathrm{SO}_{4}{ }^{2-}, \mathrm{Br}^{-}, \mathrm{NO}_{3}{ }^{-}\right.$, and $\left.\mathrm{B}^{3+}\right)$ and boron isotope compositions $\left(\delta^{11} \mathrm{~B}\right)$ of 34 halite and brines samples from the Neoproterozoic

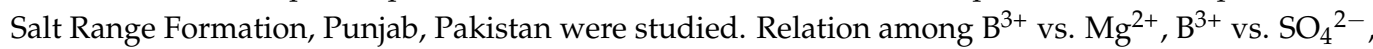
$\delta^{11} \mathrm{~B}$ vs. $\mathrm{B}^{3+}$, and $\delta^{11} \mathrm{~B}$ vs $\mathrm{K}^{+}$were observed, they indicated that these elements originate from multiple sources and the end members were identified as seawater, $\mathrm{B}$ desorption from clays, and meteoric precipitation. Halite samples of the area under study displayed a $\mathrm{Na}-\mathrm{HCO}_{3}$-type to Ca-Cl type sedimentary basin of deposition, on $\delta^{11} \mathrm{~B}$ vs. $1 / \mathrm{B}$ plot. Molar ratios of $\mathrm{B} / \mathrm{Cl}$ vs. $\delta^{11} \mathrm{~B}$ revealed the addition of $\mathrm{B}$ in some of the studied samples from desorption of clay minerals. This type of diagenetic desorption of $\mathrm{B}$ from clays is the consequence of a stress driven mechanism, generated in the proximity of a decollement zone. Results confirm that the number of B stable isotopes that fractionate between the brine and the halite is low. The halite $\delta^{11} \mathrm{~B}$ from the Salt Range Formation vary from +2.1 to $+24.4 \%$, compared to +17.3 to $+26.1 \%$ in the salt pool brines, and suggest that boron isotope compositions are controlled by the $\delta^{11} \mathrm{~B}$ of the $\mathrm{B}$ sources. The positive relationship between the boron content and the corresponding $\delta^{11} \mathrm{~B}$ indicates a higher salinity and drier paleoclimate conditions during the formation process, associated with a high evaporation rate in the Late Neoproterozoic time. Presence of elevated $\delta^{11} \mathrm{~B}$ in the present study, demonstrate compatibility with other marine basins of the world, arising the need for further investigations to better characterize the ${ }^{11} \mathrm{~B}$-enriching processes.
\end{abstract}

Keywords: halite; brine; boron isotopes; geochemistry; salt range formation

\section{Introduction}

Geochemically, Boron (B) is a lithophile light weight trace element, and classified as a semimetal [1,2]. It has variable oxidation states, but most commonly it occurs as +3 [3]. Boron possesses two natural stable isotopes $\delta^{10} \mathrm{~B}$ and $\delta^{11} \mathrm{~B}$, whose abundance is 19.9 and 80.1 percent, respectively [4]. Relative large mass difference between its two 
stable isotopes, lead to significant $B$ isotope fractionations in nature [2,5]. Small ionic size and high oxidation state of $\mathrm{B}$ make it incompatible during the magmatic to hydrothermal processes [6-8]. Boron is an important indicator of low temperature geochemical processes $[7,9,10]$, the abundance of $\delta^{11} \mathrm{~B}$ is informative for the reconstruction of paleo-oceanic $\mathrm{pH}$, thus it is a precursor to evaluate the depositional environment of marine carbonate rocks [11]. Furthermore, positive $\delta^{11} \mathrm{~B}$ values are related to seawater and brine evaporates while negative values are common in the primitive mantle [12]. During progressive metamorphism, boron shows depletion and is found more in phyllite as compared to migmatites and granulites, even though boron also enriches in metasomatic minerals [13]. Fluid-mobile elements (B, As, and $\mathrm{Sb}$ ) are valuable to discriminate fore, main and back arc of a subducting slab $[14,15]$. In addition to the above, geochemical advancement of thermal fluids and borate deposits [16], sources of saline groundwater [17], and the reconstruction of atmospheric $\mathrm{CO}_{2}$ levels $[18,19]$ can also be predicted.

The $\delta^{11} \mathrm{~B}$ isotope compositions of evaporites and brines have been extensively used to trace paleo-salinities $[5,20]$ and to discriminate and characterize marine and non-marine depositional environments $[4,18,21,22]$. The coupling of $\delta^{11} \mathrm{~B}$ stable isotopes and of elemental chemistry has been used to trace the origin and define geochemical processes involved in the formation of brines, evaporites and sediments [20]. Studies have focused on $\delta^{11} \mathrm{~B}$ measured in brines $[23,24]$ from different salt lakes and results suggest that they are influenced by the evaporation conditions and surrounding supplies of water, making $\delta^{11} \mathrm{~B}$ isotopes excellent tracers of the origin of these brines.

Pakistan has two main salt deposits regions: the Salt Range area and Kohat Plateau [25]. The Salt Range is one of the interesting and important geological features of Pakistan and designated as museum of geology. It is remnant of the collision between the Indian and Eurasian plates and considered as the youngest and most southern part of the Himalaya in Western Pakistan [26]. Salt Range is globally famous for the exposure of rocks from Precambrian to the Pleistocene age with four regional and local scale unconformities. The area displays wide varieties of structural styles, salt tectonics, and deposition in varied depositional settings. The Salt Range Formation is one of the excellent laboratory experiments to display the evaporative system in Pakistan, but unfortunately it is the least studied formation, particularly with reference to isotopic studies [26,27].

In this study, elemental and B stable isotope $\left(\delta^{11} \mathrm{~B}\right)$ compositions of halite and brines from the oldest member of the Salt Range Formation were made with the objectives of: (1) identifying the elements that control the budget of boron; (2) constraining the processes responsible for the incorporation of $B$ from the brines into the halite; (3) understanding the corresponding $\delta^{11} \mathrm{~B}$ isotopes behavior to identify the paleoclimatic conditions and compare the variations in $\delta^{11} \mathrm{~B}$ isotopes and its fractionation between halite and brines in a distinctive sedimentary basin system.

\section{Geological Settings}

The Salt Range (SR) covers an area of about $180 \mathrm{~km}$ long $\times 85 \mathrm{~km}$ wide and is located between $32^{\circ} 23^{\prime}-33^{\circ} 00^{\prime} \mathrm{N}$ and $71^{\circ} 30^{\prime}-73^{\circ} 30^{\prime} \mathrm{E}$ at the southern border of the Potwar Basin in Pakistan (Figure 1). Structurally, the SR results of tectonic influences that occurred in the advanced stages of the Himalayan orogeny about $67 \mathrm{Ma}$ ago [28]. This dense and incompetent formation played a significant role in determining the structure of the area [29]. The SR presents a complicated salt anticlinorium with a chain of salt anticlines, commonly presenting block thrusting. The slope of the SR towards the Potwar Basin is gentle and both the Potwar Basin and the SR form a large allochthones slab [30,31]. The deformation style is distinct between the southern and the northern part of the Potwar Basin, resulting from the existence of the evaporitic Salt Range Formation [32]. The SR itself emerged following the movement of the Potwar Plateau towards south, supported by an E-W striking and down to the north basement normal fault [33]. 


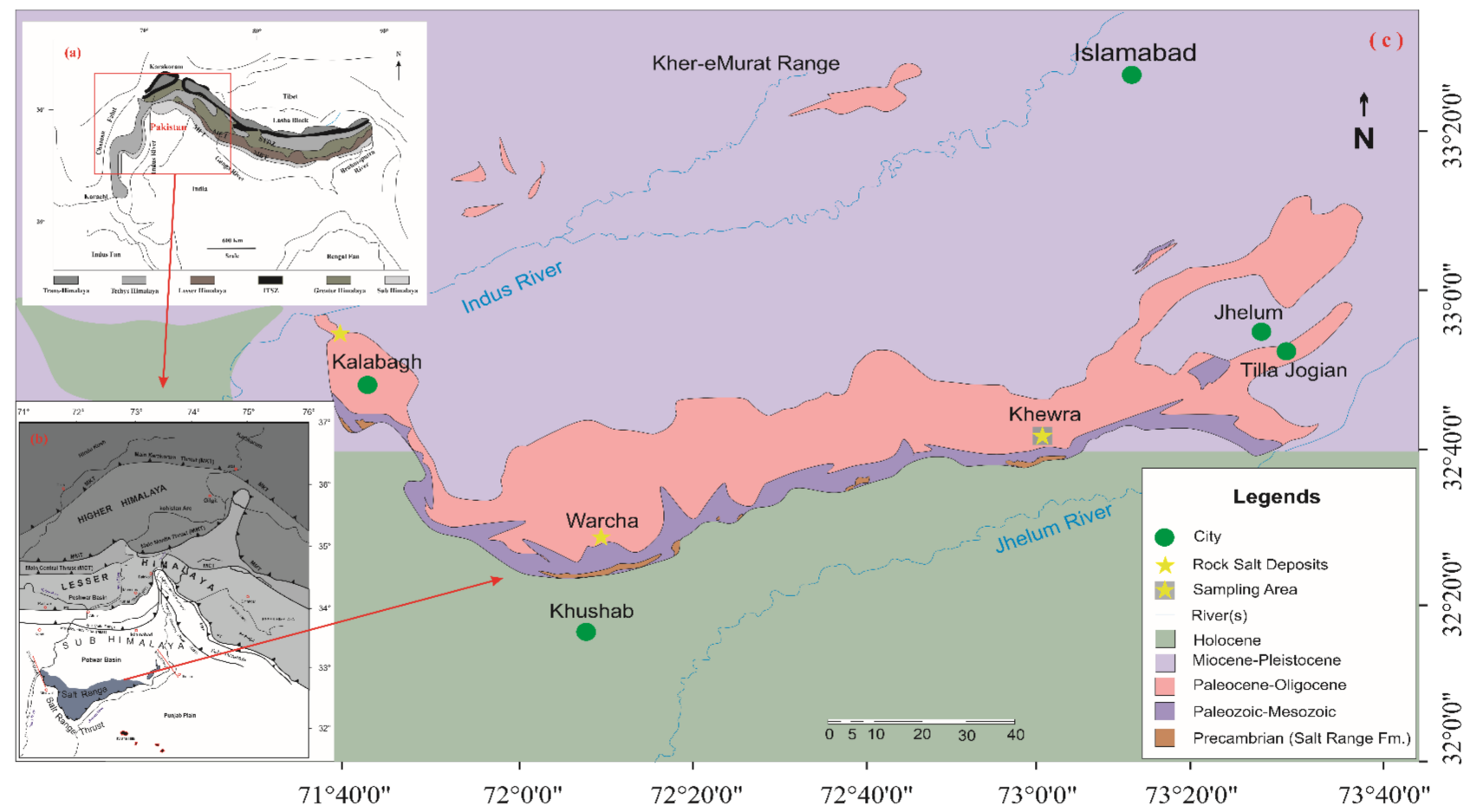

Figure 1. (a) Regional tectonic map showing the Himalayan Chain. (b) General Tectonic map of Northern Pakistan (modified after Kazmi and Rana 1982 [25]). (c) Geological map of the Salt Range and adjoining area (modified from Ghazi et al., $2015[30])$.

Stratigraphically, the exposed strata in the SR display a fairly complete range from the Cambrian to the Tertiary (Figures 2 and 3). Rocks older than the Eocambrian are generally not exposed but a few outcrops can be found (Figure 1b) in the Kirana and Sangla hills of the Punjab plains (southeast of the SR [34]). The terms East, Central, and Western Salt Range were introduced by Krishnan (1966) and later Gee and Gee (1989), dividing the SR into three main parts: (i) The Eastern SR (from Jogi Tilla to Khewra), (ii) the Central SR (from Khewra to Warchha), and (iii) the Western SR (from Sakesar to Kalabagh) (Figure 1). The SR is wider in its middle section (between Khewra and Warchha) where it makes up for one of the best successions of the Eocambrian period.

The SR Formation represents the oldest section of the SR area (Figure 2). It was formed in Late Neoproterozoic time, associated with rifting of super continent Pannotia, nearly $560 \mathrm{Ma}$ ago [35]. Its thickness is approximately $800-2000 \mathrm{~m}$ [36]. The SR Formation is mainly formed of halite, anhydrite, dolomite, gypsum, and, sporadically, oil shale [37]. The SR Formation is divided into three members based on their location and occurrence: (i) the Billianwala Salt Member, (ii) the Bandarkas Gypsum Member, and (iii) the Sahwal Marl Member (Figure 2A). These three units are outcrop in the Khewra Gorge (type locality: Khewra sandstone). The Billianwala Salt Member incorporates marl, thick seams of halite, and potash seams. The Bandarkas Gypsum Member display marl with important deposits of gypsum that range from crystalline to non-crystalline [37]. The Sahwal Marl Member consists of $(\sim 2-4 \mathrm{~m})$ marl and thick seams of halite [25,26]. The Billianwala Salt Member is observed in the Khewra salt mine and is divided into seven seams, three in the upper group called the Buggy complex, and four in the lower group called the Pharwala complex. These two groups are separated by a layer of interbedded (salt and marl) seams. The Buggy complex group includes: (1) the North Buggy Salt Seam, (2) the Buggy Seam, and (3) the Sujjawal. The Pharwala Complex include: (1) the upper Pharwala Seam, (2) the Middle Pharwala Seam, (3) the South Pharwala Seam, and (4) the Low-level tunnel Seam (Figure 3).

The Khewra area is an asymmetrical dome cut by the Khewra stream, that exposes a significant stratigraphic part of this area. A complete sequence including halite facies 
of the SR Formation is exposed $1 \mathrm{~km}$ from the mouth of the Khewra salt mine (Hussain et al., 2020 [26]). All exposed strata in the Khewra salt mines are part of the lower or main saline marls.

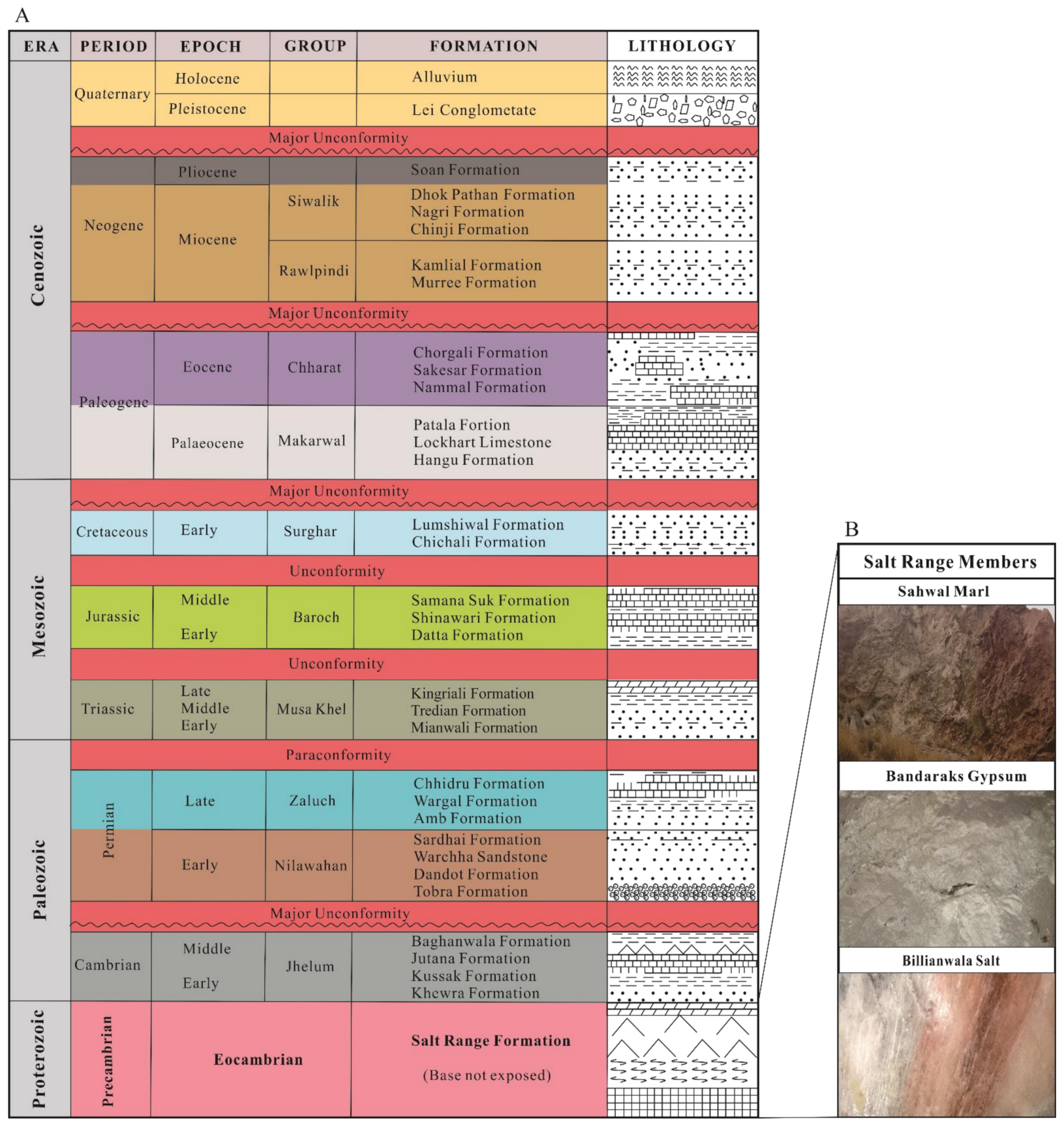

Figure 2. (A) Stratigraphic column of the units within the study area. Lithologies of the different formations are also reported (after Grelaud et al., 2002 [31]). (B) The Salt Range Member subdivisions (after Sameeni, 2009 [37] and Ghazi et al., $2015[30])$.

\section{Material and Methods}

\subsection{Sampling}

Halite and brine were sampled during 3 sampling campaigns at the Kherawa salt mine (SR Formation). All exposed seams were sampled. Sample locations are detailed in Tables 1 and 2, and Figure 3. Only fresh and unweathered halite samples were collected. For each site, liquid samples were collected in acid-washed $500 \mathrm{~mL}$ polyethylene bottles, rinsed at least three times with the sample water. 


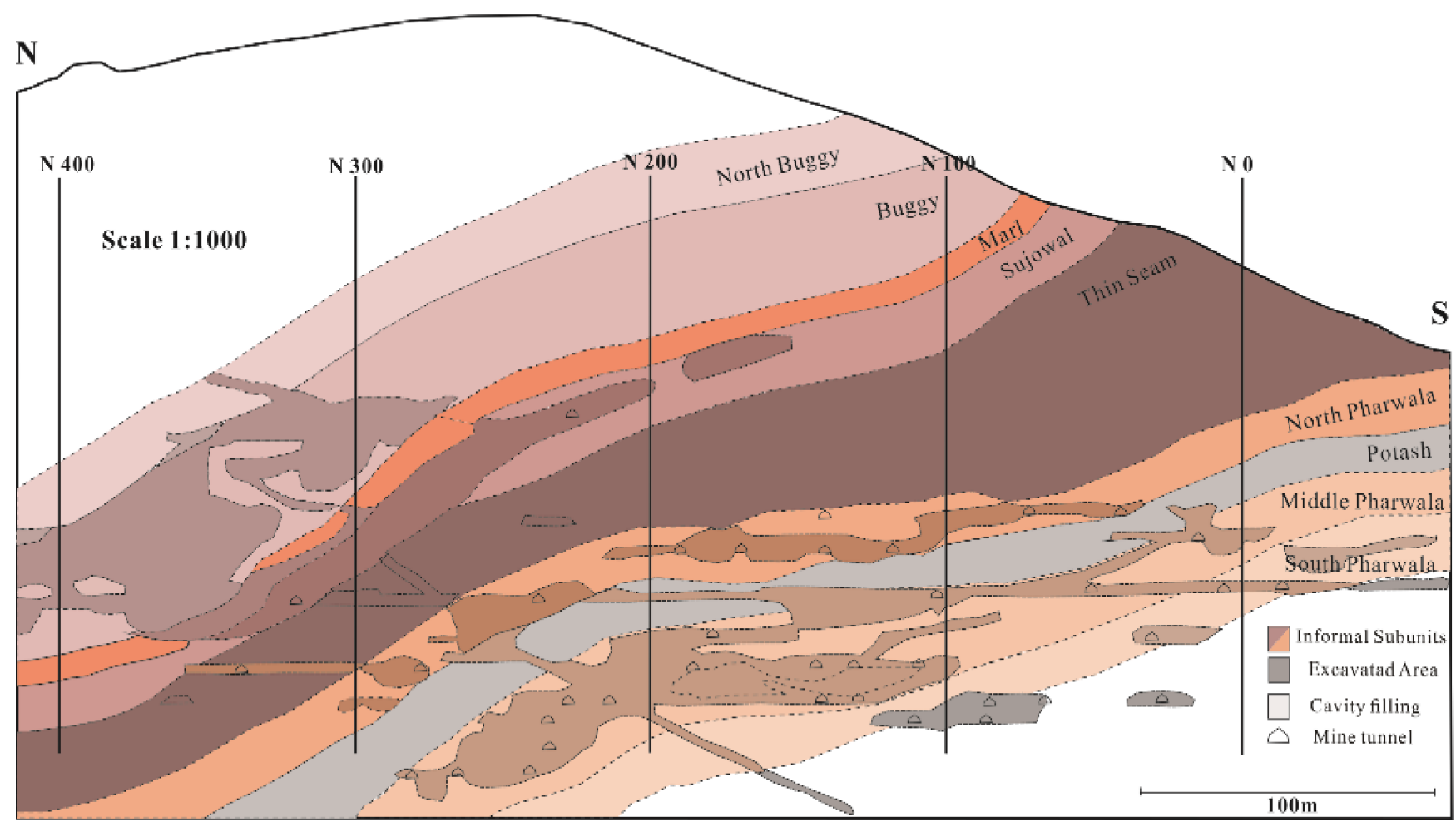

Figure 3. Study area and distribution of the informal sub-units at the Salt Range Formation in the Khewra Mine (after Hussain et al., 2020 [26]).

\subsection{Processing Procedure}

All measurements were performed at the Salt Lakes Analytical and Testing Department, Qinghai Institute of Salt Lakes, Chinese Academy of Sciences. Halite samples were first dissolved in deionized water (deionized at least four times). As the brines generally present very high TDS concentrations, we prepared each sample to ultimately obtain a solution having a TDS of $\sim 200 \mathrm{mg} / \mathrm{L}$. Concentrations of $\mathrm{K}^{+}, \mathrm{Na}^{+}, \mathrm{Ca}^{2+}$, and $\mathrm{Mg}^{2+}$ were measured by using Plasma spectrometry (ICAP6500DUO, Waltham, MA, USA) with an analytical error of less than $\pm 5 \% . \mathrm{Br}^{-}, \mathrm{NO}_{3}{ }^{-}$, and $\mathrm{SO}_{4}{ }^{2-}$ concentrations were determined by Ion Chromatography (IC-5000+, Thermo Fisher USA; error $<1.0 \%$ ) and $\mathrm{Cl}^{-}$by chemical mercurimetry (with an accuracy higher than 0.3\%; ISL, CAS, 1988, Xining, China).

$\delta^{11} \mathrm{~B}$ was measured by Positive Thermal Ionization Mass Spectrometry (TIMS-TRITON, Waltham, MA, USA) with a detection limit of 1-320 a.m.u [38]. For each sample $10 \mathrm{mg}$ of halite were dissolved in highly deionized water $(B<100 \mathrm{ng} / \mathrm{L})$ and centrifuged for approximately 15-20 min to remove any detrital impurity. A 2-columns procedure was then used for separating and purifying $B$ in the sample: the first column contained mixed cation-anion resins (250-350 mesh strongly acidic cation resin, Dowex $50 \mathrm{~W} \times 8 \mathrm{H}^{+}$, USA, and 50-100 mesh weak alkaline anion resin, Ion Exchanger II, $\mathrm{HCO}_{3}{ }^{-}$, Germany) and the second column an Amberlite IRA 743 Boron-specific resin. The Amberlite IRA 743 Boron-specific resin was first conditioned with $\mathrm{HCl}$ and then leached with a saturated $\mathrm{NaHCO}_{3}$ solution. Finally, the column was washed with deionized (DI) water to achieve a neutral $\mathrm{pH}[39,40]$. Boron purification and separation were accomplished following three steps.

The purification steps consisted in passing the sample solution through the B-specific resin at $2.5 \mathrm{~mL} \cdot \mathrm{min}^{-1}$. B was then eluted with $500 \mu \mathrm{L}$ of $\mathrm{HCl}\left(0.1 \mathrm{~mol} \cdot \mathrm{L}^{-1} ; \leq 70{ }^{\circ} \mathrm{C}\right)$. Subsequently, $0.5 \mathrm{~mL}$ of the solution was concentrated and purified in a furnace at a temperature $<65^{\circ} \mathrm{C}$ after what it was loaded into the mixed anion and cation exchange resin column. The leachate was collected using $15 \mathrm{~mL}$ of deionized water. Appropriate amounts of $\mathrm{Cs}_{2} \mathrm{CO}_{3}$ and mannitol were added to the solution in order to keep the molar 
ratio of $B / C$ s at $2: 1$ and that of $B /$ mannitol at $1: 1$. Finally, the solution was concentrated, by heating at $\sim 60{ }^{\circ} \mathrm{C}$, to a $\mathrm{B}$ concentration of $1 \mathrm{~g} \cdot \mathrm{L}^{-1}$ before analysis on the TIMS.

The measurement of the B isotope ratios followed the one described by Xiao et al. [41,42]. Isotope ratios measurements were made on a Triton thermal ionization mass spectrometer (Thermo Fisher Scientific). $2.5 \mu \mathrm{L}$ of graphite slurry and the sample solution were loaded sequentially (slurry first and then the sample solution when the slurry was dry) on a single tantalum filament that had previously been degassed under vacuum for $1 \mathrm{~h}$ at a current of 3.0A. The ${ }^{11} \mathrm{~B} /{ }^{10} \mathrm{~B}$ ratio was calculated as $\mathrm{R}_{309} /{ }_{308}-0.00078$ [38]. The corresponding $\mathrm{B}$ isotope composition was expressed using the $\delta^{11} \mathrm{~B}$ notation:

$$
\delta^{11} \mathrm{~B}(\%)=\left[\begin{array}{l}
\frac{{ }^{11} \mathrm{~B}}{{ }^{10} \mathrm{~B}} \text { sample } \\
\frac{{ }^{11} \mathrm{~B}}{{ }^{10} \mathrm{~B}} \text { standard }
\end{array}\right] .10^{3}
$$

The average ${ }^{11} \mathrm{~B} /{ }^{10} \mathrm{~B}$ value for the standard NIST SRM 951 was $4.05263 \pm 0.00077$ $(n=9 ; 2 \alpha=0.02 \%)$ consistent with previous studies (e.g., [38]).

Table 1. $\delta^{11} \mathrm{~B}$ values and ionic composition of halite with sample locations. SPW = South Pharwala, KS = Potash Seam, MPW = Middle Pharwala, NPW = North Pharwala, TS = Thin Seam, S = Sujowal, B = Buggy, NB = North Buggy (names are same as in Figure 3). KHY (H) and KHY (B) correspond to salt samples from two different pools, from where we collected the modern brines.

\begin{tabular}{|c|c|c|c|c|c|c|c|c|c|c|c|c|}
\hline Sample & Location & $\begin{array}{c}\mathrm{Cl}^{-} \\
\text {(Wt. \%) }\end{array}$ & $\begin{array}{c}\mathrm{SO}_{4}^{2-} \\
\text { (Wt. \%) }\end{array}$ & $\begin{array}{c}\mathrm{Na}^{+} \\
\text {(Wt. \%) }\end{array}$ & $\begin{array}{c}\mathbf{K}^{+} \\
\text {(Wt. \%) }\end{array}$ & $\begin{array}{c}\mathrm{Ca}^{2+} \\
\text { (Wt. \%) }\end{array}$ & $\begin{array}{c}\mathrm{Mg}^{2+} \\
\text { (Wt. \%) }\end{array}$ & $\begin{array}{c}\mathbf{B}^{3+} \\
\text { (Wt. \%) }\end{array}$ & $\begin{array}{c}\mathrm{Br}^{-} \\
\text {(Wt. \%) }\end{array}$ & $\begin{array}{c}\mathrm{NO}_{3}{ }^{-} \\
(\mathrm{Wt} . \%)\end{array}$ & $\begin{array}{l}\mathcal{\delta}^{11} \mathrm{~B} \\
(\% \mathrm{o})\end{array}$ & $\begin{array}{c}\text { Error }( \pm) \\
\quad(\%)\end{array}$ \\
\hline KH17-1 & NLLT & 51.05 & 6.96 & 36.41 & 0.32 & 0.23 & 0.13 & 0.0034 & 0.0080 & 0.0375 & 13.75 & 0.23 \\
\hline KH17-2 & SPW & 59.43 & 1.36 & 38.71 & 0.22 & 0.21 & 0.06 & 0.0003 & 0.0105 & 0.1262 & 2.13 & 0.13 \\
\hline KH17-3 & SPW & 59.35 & 1.47 & 38.50 & 0.32 & 0.24 & 0.13 & 0.0005 & 0.0089 & 0.1366 & 7.04 & 0.20 \\
\hline КH17-4 & KS & 36.68 & 27.21 & 24.21 & 7.55 & 0.03 & 4.31 & 0.0052 & 0.0097 & 0.1117 & 16.25 & 0.16 \\
\hline KH17-5 & KS & 44.85 & 0.31 & 22.30 & 9.41 & 0.01 & 0.06 & 0.0003 & 0.0340 & 0.0948 & 9.19 & 0.14 \\
\hline KH17-6 & MPW & 60.28 & 0.16 & 39.00 & 0.15 & 0.02 & 0.02 & 0.0012 & 0.0092 & 0.1534 & 22.04 & 0.03 \\
\hline KH17-7 & KS & 47.61 & 8.10 & 31.91 & 1.44 & 1.35 & 0.65 & 0.0106 & 0.0064 & 0.0326 & 17.44 & 0.26 \\
\hline KH17-8 & KS & 40.33 & 7.71 & 19.14 & 9.73 & 0.03 & 1.38 & 0.0014 & 0.0281 & 0.0904 & 17.08 & 0.05 \\
\hline KH17-9 & NPW & 54.14 & 3.81 & 35.40 & 0.77 & 0.52 & 0.45 & 0.0072 & 0.0093 & 0.0239 & 19.18 & 0.21 \\
\hline KH17-10 & NPW & 60.45 & 0.12 & 39.18 & 0.06 & 0.04 & 0.01 & 0.0000 & 0.0074 & 0.1795 & - & - \\
\hline KH17-11 & NPW & 60.16 & 0.29 & 38.94 & 0.13 & 0.10 & 0.08 & 0.0000 & 0.0082 & 0.0658 & 14.31 & 0.08 \\
\hline КН17-12 & NPW & 45.65 & 6.73 & 30.43 & 1.30 & 1.18 & 0.49 & 0.0082 & 0.0054 & 0.0300 & 17.05 & 0.27 \\
\hline КН17-13 & TS & 60.30 & 0.20 & 39.05 & 0.10 & 0.04 & 0.02 & 0.0001 & 0.0100 & 0.1863 & 17.29 & 0.12 \\
\hline KH17-14 & TS & 49.69 & 12.67 & 31.31 & 3.80 & 0.02 & 2.5 & 0.0022 & 0.0240 & 0.1391 & 13.67 & 0.09 \\
\hline KH17-15 & TS & 57.85 & 3.15 & 38.74 & 0.10 & 0.07 & 0.08 & 0.0001 & 0.0111 & 0.0687 & 14.53 & 0.28 \\
\hline KH17-16 & TS & 58.63 & 2.21 & 38.62 & 0.27 & 0.25 & 0.02 & 0.0001 & 0.0076 & 0.0992 & 18.16 & 0.10 \\
\hline KH17-17 & MPW & 60.49 & 0.18 & 39.21 & 0.05 & 0.02 & 0.04 & 0.0003 & 0.0243 & 0.1752 & 21.69 & 0.26 \\
\hline KH17-18 & MPW & 58.27 & 2.69 & 38.02 & 0.55 & 0.19 & 0.28 & 0.0005 & 0.0072 & 0.1231 & 16.8 & 0.08 \\
\hline КH17-19 & MPW & 60.19 & 0.52 & 39.09 & 0.10 & 0.07 & 0.03 & 0.0003 & 0.0096 & 0.0993 & 20.84 & 0.20 \\
\hline KH17-20 & MPW & 53.49 & 0.40 & 31.01 & 2.29 & 0.02 & 1.35 & 0.0005 & 0.0085 & 0.0734 & 21.2 & 0.05 \\
\hline КH17-21 & $\mathrm{S}$ & 49.30 & 12.68 & 37.90 & 0.04 & 0.02 & 0.06 & 0.0009 & 0.0183 & 0.1451 & 24.38 & 0.26 \\
\hline KH17-23 & $\mathrm{S}$ & 59.67 & 1.11 & 39.03 & 0.08 & 0.05 & 0.05 & 0.0000 & 0.0095 & 0.1314 & - & - \\
\hline КН17-22 & $\mathrm{S}$ & 60.22 & 0.47 & 39.04 & 0.14 & 0.08 & 0.04 & 0.0001 & 0.0103 & 0.0848 & 12.07 & 0.16 \\
\hline КН17-24 & B & 59.69 & 1.13 & 39.03 & 0.04 & 0.01 & 0.11 & 0.0005 & 0.0075 & 0.1175 & 20.14 & 0.03 \\
\hline KH17-25 & B & 59.37 & 1.54 & 38.56 & 0.16 & 0.11 & 0.25 & 0.0004 & 0.0091 & 0.1158 & 15.98 & 0.20 \\
\hline KH17-26 & NB & 59.33 & 1.48 & 38.52 & 0.29 & 0.27 & 0.11 & 0.0020 & 0.0078 & 0.0972 & 21.95 & 0.15 \\
\hline КH17-27 & NB & 56.31 & 4.83 & 36.54 & 0.20 & 0.13 & 0.05 & 0.0014 & 0.0076 & 0.0290 & 18.31 & 0.12 \\
\hline K17-28 & NB & 54.08 & 7.42 & 38.26 & 0.05 & 0.008 & 0.18 & 0.0007 & 0.0229 & 0.1530 & 22.13 & 0.13 \\
\hline $\mathrm{KHY}(\mathrm{H})$ & & 47.69 & 11.52 & 30.35 & 3.20 & 0.04 & 2.3 & 0.0023 & 0.0240 & 0.1391 & 12.3 & 0.3 \\
\hline KHY(B) & & 89.12 & 6.15 & 39.66 & 4.67 & 1.47 & 71262 & 0.0002 & 0.0131 & 0.0302 & 17.9 & - \\
\hline
\end{tabular}

Table 2. $\delta^{11} \mathrm{~B}$ values and ionic composition of modern brines (halite dissolved by meteoric water) from the Salt Range Formation.

\begin{tabular}{|c|c|c|c|c|c|c|c|c|c|c|}
\hline Sample & $\begin{array}{c}\mathrm{Cl}^{-} \\
(\mathrm{mg} / \mathrm{L})\end{array}$ & $\begin{array}{l}\mathrm{SO}_{4}^{2-} \\
(\mathrm{mg} / \mathrm{L})\end{array}$ & $\begin{array}{c}\mathrm{Na}^{+} \\
(\mathrm{mg} / \mathrm{L})\end{array}$ & $\begin{array}{c}\mathrm{K}^{+} \\
(\mathrm{mg} / \mathrm{L})\end{array}$ & $\begin{array}{c}\mathrm{Ca}^{2+} \\
(\mathrm{mg} / \mathrm{L})\end{array}$ & $\begin{array}{c}\mathrm{Mg}^{2+} \\
(\mathrm{mg} / \mathrm{L})\end{array}$ & $\begin{array}{c}B^{3+} \\
(\mathrm{mg} / \mathrm{L})\end{array}$ & $\begin{array}{c}\mathrm{Br}^{-} \\
(\mathrm{mg} / \mathrm{L})\end{array}$ & $\begin{array}{l}\mathrm{NO}_{3}^{-} \\
(\mathrm{mg} / \mathrm{L})\end{array}$ & $\begin{array}{c}\delta^{11} B \\
(\%)\end{array}$ \\
\hline KH-PB-1 & $1,725,361$ & 319,765 & 956,750 & 71,600 & 2592.5 & 85,875 & 13.87 & 410.2 & 437.4 & 24.04 \\
\hline KH-PB-2 & $1,711,262$ & 155,902 & $915,061.5$ & $36,803.7$ & 4212.495 & $36,997.2$ & 6.52 & 197 & 956.4 & 24.2 \\
\hline KH-PB-3 & $1,708,814$ & 131,128 & - & $45,085.1$ & $14,270.85$ & $42,478.8$ & 7.25 & 188.8 & 262.4 & 26.13 \\
\hline KH-PB-4 & 720,827 & 49,306 & - & $59,818.2$ & 119,184 & 43,914 & 14.93 & 125.6 & 632.2 & 17.31 \\
\hline
\end{tabular}




\section{Discussion}

\subsection{B Isotope Compositions and Ion Concentrations}

Halite and brines ion composition and $\delta^{11} \mathrm{~B}$ are reported in Tables 1 and 2. Boron exists under two forms in halite, either incorporated in the lattice [23] or as fluid inclusions [21]. When incorporated into the halite lattice B coprecipitates with gypsum or carbonates [21,43]. Figure 4 reports variations of both various ion concentrations and $\delta^{11} \mathrm{~B}$ in the halite samples. $\mathrm{Ca}^{2+}$ and $\mathrm{Mg}^{2+}$ (Figure 4A) data follows two distinct linear trends that identify at least three halite groups: (i) A first group, characterized by both low $\mathrm{Ca}^{2+}$ and low $\mathrm{Mg}^{2+}$ concentrations (zone i), (ii) a second group that seems to be influenced by an end member characterized by high $\mathrm{Mg}^{2+}$ and low $\mathrm{Ca}^{2+}$ concentrations (zone ii; $\mathrm{r}^{2}=0.78$ ), and a third group (zone iii) impacted by an endmember with significantly higher $\mathrm{Ca}^{2+}$ and moderate

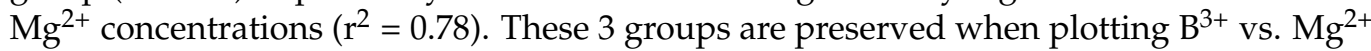
(Figure 4B) and vs $\mathrm{SO}_{4}{ }^{2-}$ (Figure $4 \mathrm{C}$ ). These highlight the fact that the $\mathrm{B}^{3+}$ present in SR halite samples probably results from multiple sources.
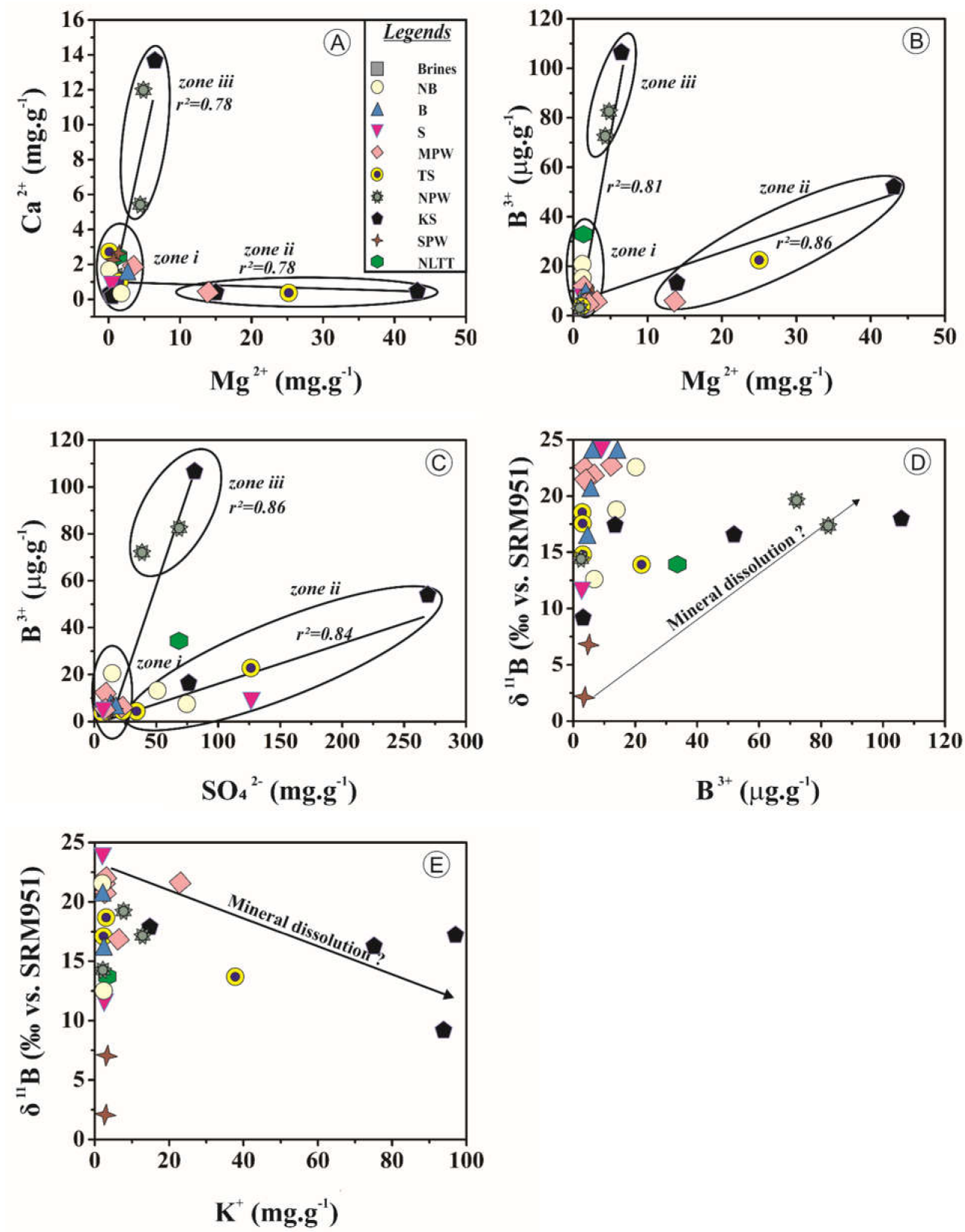

Figure 4. Ion-ion and ion- $\delta 11 \mathrm{~B}$ covariations in the halite samples. (A) $\mathrm{Ca}^{2+}$ vs. $\mathrm{Mg}^{2+}$. (B) $\mathrm{B}^{3+} \mathrm{vs}^{-\mathrm{Mg}^{2+}}$. (C) $\mathrm{B}^{3+}$ vs. $\mathrm{SO}_{4}^{2-}$. (D) $\delta^{11}$ B vs. B ${ }^{3+}$. (E) $\delta^{11} \mathrm{~B}$ vs. $\mathrm{K}^{+}$. 
Probably, in the late Neoproterozoic time, Pannotian subcontinents faced intense tectonics in form of collision, extension, and subsidence around Salt Range area. This influenced of the budget of $B$ in SR Formation due to variation in salinity, $\mathrm{pH}$, redox condition [44]. While the correlation of $\mathrm{B}^{3+}$ with $\mathrm{Mg}^{2+}$ and $\mathrm{SO}_{4}{ }^{2-}$ at high concentrations is consistent with the dissolution of carbonate and gypsum minerals, at lower concentrations these correlations hint at fluid inclusions as the sources of these elements, in agreement with Fan et al. [5].

Previous studies of salt lake brines (e.g., Qaidam Basin) showed that $\delta^{11} \mathrm{~B}$ isotope compositions roughly correlate with the $\mathrm{Ca} / \mathrm{Cl}$ ratio as a result of the potential influence of $\mathrm{Ca}^{2+}$ type brines [24]. To test this hypothesis, we compared the $\mathrm{B} / \mathrm{Cl}, \mathrm{Mg} / \mathrm{Cl}, \mathrm{Ca} / \mathrm{Cl}$, and $\mathrm{K} / \mathrm{Cl}$ ratios of halite samples with their corresponding $\delta^{11} \mathrm{~B}$ values but our results did not show any significant correlation between $\delta^{11} \mathrm{~B}$ and any of the aforementioned ratios. On the other hand, $\mathrm{K}^{+}$and $\mathrm{B}^{3+}$ in the halite samples display a weak to moderate correlation with $\delta^{11} \mathrm{~B}$ at the higher concentrations that comfort the hypothesis that these correspond to mineral dissolution (Figure $4 \mathrm{D}, \mathrm{E}$ ). This is similar to the trends observed in the Qarhan playa $[5,20]$ but differ from the results from the Mahai and Lenghu salt lake brines in China [24]. The halite mineral composition of the SR formation is quite complex. The salt layers mainly contain halite with gypsum, dolomite, occasionally shale and quartz minerals [26]. Analysis by X-ray diffraction (XRD) indicated that the halite layers also contain significant amounts of magnesium salts (carnallite, kainite, kieserite, polyhalite, etc.). This supports the hypothesis that the elevated $\mathrm{Mg}^{2+}$ contents that we are observing in Figure 4 result from the involvement or the partial dissolution of Mg-type minerals. The trimmed $\mathrm{Mg}^{2+}$ might be as well an indicator of the contribution of several distinct sources. Analysis by XRD of the halite samples revealed the presence of Mg salts, hinting that the low $\mathrm{Mg}^{2+}$ and $\mathrm{B}^{3+}$ contents originate from fluid inclusions. This is in agreement with the results from evaporation experiments [21] and from the study of the ISL1A halite sample by Fan et al. [5]. Still, further studies are necessary to better understand what may be the source of the low $\mathrm{Ca}^{2+}$ if the low $\mathrm{Mg}^{2+}$ and $\mathrm{B}^{3+}$ values come from the fluid inclusions.

\subsection{Boron Sources}

Vengosh et al. $[23,45]$ isotopically distinguished marine $\left(\delta^{11} \mathrm{~B}=+57 \%\right)$ and non-marine $\left(\delta^{11} \mathrm{~B}<+39 \%\right)$ brines from SW $\left(\delta^{11} \mathrm{~B}=+39 \%\right)$. However, SR brines $\left(\delta^{11} \mathrm{~B}\right.$ from 17 to $26 \%$ ) and halite $\left(\delta^{11} \mathrm{~B}\right.$ from 2 to $24 \%$ ) samples, as well as the inferior value reported by Williams et al. [46] for the Gulf Coast $\left(\delta^{11} \mathrm{~B}=+10 \%\right.$ ), hints that when diagenetic processes alter salt water resulting formations and brines it may ultimately shift their $\delta^{11} \mathrm{~B}$ leading to non-marine characteristics.

This may result from the fact that the authors did not consider potential B inputs from clay minerals. It is now well established that clay desorption can affect marine pore-waters without releasing $\mathrm{Cl}$ [47]. Figure 5A indicates that some SR samples lie in the $\delta^{11} \mathrm{~B}$ range corresponding to clay desorption, reflecting the fact that several factors may have modified their initial isotope compositions, for example: multiple transgressions and regressions [30], multiple evaporation and recrystallization cycles [48] or meteoric dilution [49]. Possibly, complex tectonics at the Neoproterozoic time, were responsible for marine or fresh water evaporate deposition of study area. 


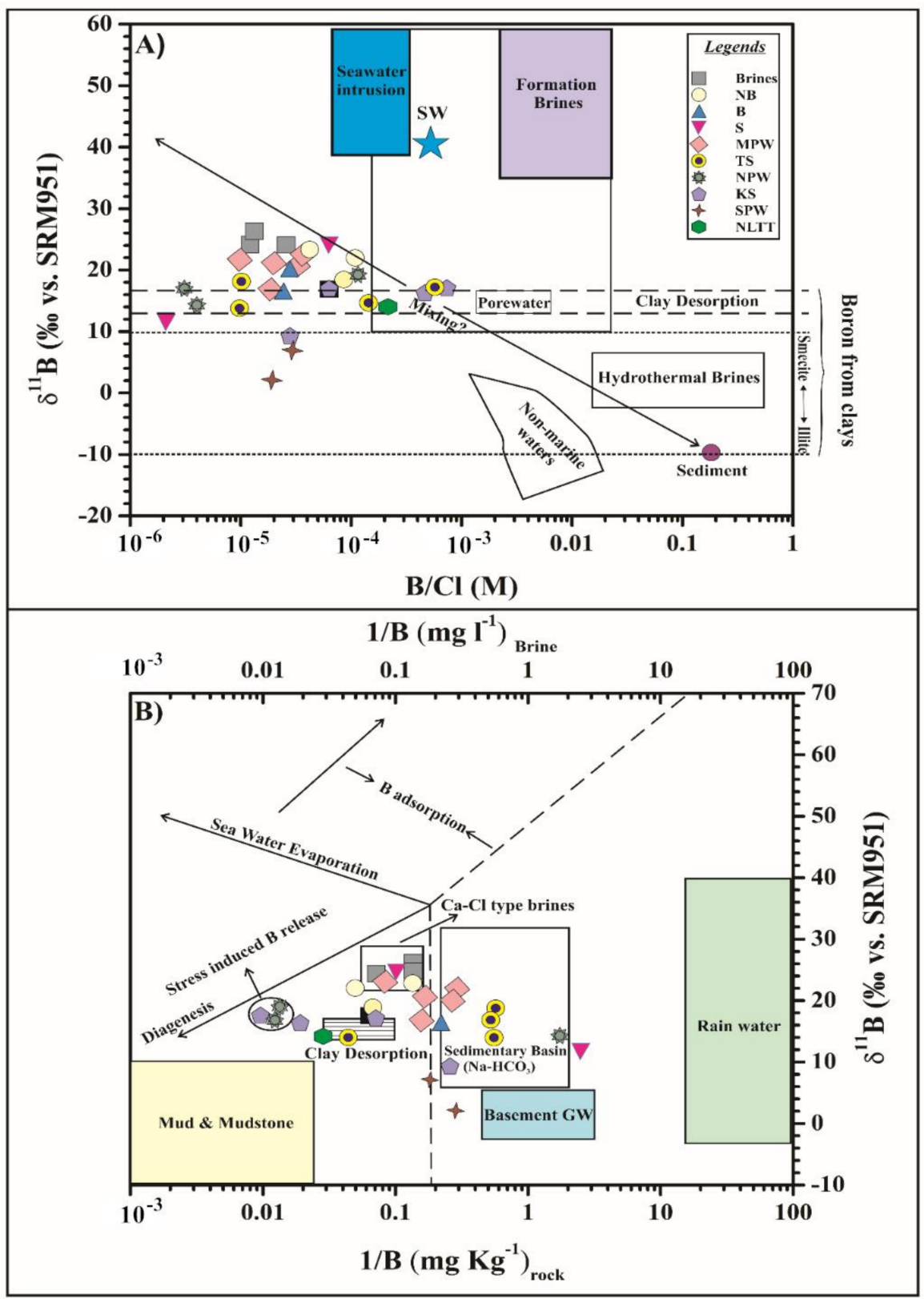

Figure 5. Covariations of $\delta^{11} \mathrm{~B}$ and $(\mathrm{A}) \mathrm{B} / \mathrm{Cl}$ molar ratios, and $(\mathbf{B}) 1 / \mathrm{B}$ ratios. Characteristics of the different reservoirs are adapted from Boschetti et al., 2015 [49].

When plotting the classical 1/B concentration vs. the $\delta^{11} B$ (Figure $5 B$ ), most of SR samples (B, TS, and MWP) fall into the ranges of the $\mathrm{Na}-\mathrm{HCO}_{3}$-type sedimentary basins, which can most likely be explained by the mixing of the following three end-members: (i) meteoric precipitation [50], (ii) B desorption from clays [51], and (iii) seawater. On the other hand, the brines and some of the NB and MWP samples indicate a Ca-Cl type origin. These samples also reveal information about the reigning paleoclimatic conditions as during the Phanerozoic ( 550-600 Ma) seawater shifted from a dominantly Na-K-Mg$\mathrm{Ca}-\mathrm{Cl}$ (Ca-rich) brine towards a Na-K-Mg-Cl-SO ${ }_{4}\left(\mathrm{SO}_{4}\right.$-rich) type [48]. These variations are associated with fluctuations in the seafloor spreading rates, changes in the global sea level, and with the key marine carbonates and evaporites mineralogies [52]. 
A third group of samples (Mainly formed by the KS and NPW sections) plots outside of these trends (Figure 5B) and seems to symbolize diagenetic B emitted from clay minerals following stress-driven or temperature-induced effects, as illustrated by Boschetti et al. [49] and Deyhle et al. [53]. Indeed, their B concentration ( $K S=106 \mathrm{ppm}, \mathrm{NPW}=75 \mathrm{ppm})$ and their $\delta^{11} \mathrm{~B}(\mathrm{KS}=17.44 \%, \mathrm{NPW}=19.18 \%$ ) are similar to those reported in Salvarola (Italy) for overstressed fluids by Boschetti et al. [49], as well as to fluids rising from a mud volcano reported by You et al. [54] in the vicinity of a decollement zone (i.e. basal detachment fault). Thus, the study of the B isotope compositions confirms that these samples were generated in the proximity of a decollement zone, a hypothesis that was previously suggested by Baker et al. [55] and others using other proxies.

\subsection{B isotope Fractionation between Halite and Brines in the SR Area}

Vengosh et al. [23] observed a strong enrichment in $\delta^{11} \mathrm{~B}$ (up to $30 \%$ ) in the parental brines during seawater evaporation compared to the coprecipitated halite. The authors also observed a B isotope fractionation of about $25 \%$ between the brine and the gypsum and halite. On the other hand, Liu et al. [21] worked on the evaporation of synthetic brines and showed that the halite crystallized from pure $\mathrm{NaCl}$ solutions display small $\delta^{11} \mathrm{~B}$ variations, from 10.7 to $10.8 \%$. Moreover, the $\mathrm{B}$ isotope compositions of halite formed from $\mathrm{Na}-\mathrm{Ca}-\mathrm{Cl}-\mathrm{SO}_{4}$ solutions yielded values between 7.1 and $10.7 \%$, enriched in ${ }^{11} \mathrm{~B}$, lower than the values found in other studies [23].

The isotope fractionation factor (between the pool halite and the modern brines) was calculated using following equation:

$$
\begin{aligned}
& \alpha \mathrm{A}-\mathrm{B}=\mathrm{R}_{\mathrm{A}} / \mathrm{R}_{\mathrm{B}} \quad \text { or } \\
& \mathrm{a}=\left(1000+\delta^{11} \mathrm{~B}_{\text {phase } 1}\right) /\left(1000+\delta^{11} \mathrm{~B}_{\text {phase } 2}\right) .
\end{aligned}
$$

where $\mathrm{R}$ is the ratio of the heavy over the light $\mathrm{B}$ isotope $\left(={ }^{11} \mathrm{~B} /{ }^{10} \mathrm{~B}\right)$.

The isotope fractionation factor $(\alpha)$ between recently precipitated halite (sample $\mathrm{KHY}(\mathrm{H})$ ) in Table 1 and brines KHY(B) in Table 2 is 0.9945 . On the other hand, the $\delta^{11} \mathrm{~B}$ range measured in the SR halite samples is overlapping that of the brines, and (mostly) the difference in B isotope compositions is between 1 and 10\% comparable to the one reported for the evaporation experiment [21], the Qarhan salt lake [5] and brines from the Qaidam Basin [21]. $\delta^{11} \mathrm{~B}$ of ancient halite from the SR area suggest that fluid inclusions played an important role in the overall B budget in halite. Consequently, although the SR formation and the modern brines represent two significantly different ages, we can hypothesize that the $\delta^{11} \mathrm{~B}$ of halite from the SR is representative of the paleobrine prevailing in the study area. When compared to studies from other basins (e.g., $[5,18,21]$ our results support the hypothesis that $\mathrm{B}$ isotope fractionation can be considered negligible during halite crystallization and suggest that $\delta^{11} \mathrm{~B}$ values of halite might be mainly controlled by the $\delta^{11} \mathrm{~B}$ of the source water.).

\section{4. $\delta^{11} B$ and Paleoclimate: Geological Implications}

Boron is a trace element and is relatively rich in salt lakes. Liu et al. [21] have experimentally proved that $B$ isotope fractionation is small during the evaporation process and also that chemical elements present in the halite and brines remain unchanged during this process. Thus, the B isotope composition of halite can be considered approximately equal to that in the corresponding brines. Therefore, $\delta^{11} \mathrm{~B}$ is a good proxy throughout the halite crystallization process and also gives information about the chemical and evaporation environments of salt lakes. For example, a high B content coupled to a high $\delta^{11} \mathrm{~B}$ in halite is indicative of an elevated B content in brines. 
$\mathrm{B}$ is present under two $\mathrm{pH}$-dependent forms, either boric acid (trigonal species) or borate anions (tetrahedral species). While $\mathrm{B}(\mathrm{OH})_{3}$ has generally a high ${ }^{11} \mathrm{~B}$ content, it is generally depleted in $\mathrm{B}(\mathrm{OH})_{4}[45,56]$. Previous studies on lake waters (Qinghai Lake), artificially prepared brines, salt lake brines from the Qaidam Basin [21], and seawater [23] indicated that $\delta^{11} \mathrm{~B}$ in brines increases with the decreasing $\mathrm{pH}$, and most studies revealed that the $\mathrm{pH}$ is inversely correlated to TDS $[20,24,38,57]$. As the higher B concentrations in SR halite samples corresponded to the higher TDS and the more positive $\delta^{11} \mathrm{~B}$ values, it suggests that the SR area was characterized by a high evaporation rate at the time of their formation, in agreement with the secular variations in the $\mathrm{Ca}^{2+}$ and $\mathrm{SO}_{4}{ }^{2-}$ concentrations of seawater during Phanerozoic time [52]. This result is comforted by the relationship observed in Figure $4 \mathrm{C}$ between the $\mathrm{B}$ content and its corresponding $\delta^{11} \mathrm{~B}$ in the halite samples. Moreover, these results suggest that the positive $\delta^{11} \mathrm{~B}$ values measured in halite are indicating the past presence of a high-salinity paleo-lake.

\subsection{Boron Isotopes: A Global Comparison}

While low $\delta^{11} \mathrm{~B}$ values are observed in terrestrial reservoirs, higher $\mathrm{B}$ isotope compositions are characteristic of marine reservoirs. The $\delta^{11} \mathrm{~B}$ of present-day seawater is constant at $+39.5 \%$, and is coupled to a B content of $4.5 \mathrm{ppm}$ [38]. The continental crust is relatively depleted in ${ }^{11} \mathrm{~B}$ with $\delta^{11} \mathrm{~B}$ ranging between -20 and $+7 \%$ [58]. In general, materials of marine origin (e.g., halite, brines) display positive $\delta^{11} \mathrm{~B}$. At a region scale, variations in $\delta^{11} \mathrm{~B}$ are possible, depending on local environmental conditions and source material. For example, in China, the Qiadam Basin is famous for having varying $\delta^{11} \mathrm{~B}$ among its numerous salt lakes: North and NW salt lakes brines are the most enriched in ${ }^{11} \mathrm{~B}\left(\delta^{11} \mathrm{~B}=22.2 \%\right)$, East and NE salt lakes have intermediate values $\left(\delta^{11} \mathrm{~B}=7.8 \%\right.$ ) and the salt lakes located in the center and southern sections of the Basin are relatively isotopically depleted, with an average $\delta^{11} \mathrm{~B}$ of $3.4 \%$ [24,59]. In contrast, brines from Inner Mongolia and Xinjiang display average $\delta^{11} \mathrm{~B}$ of 11.6 and $11.8 \%$, respectively [60].

Figure 6 shows a $\delta^{11} \mathrm{~B}$ comparison of halite, brines, hot springs, and river waters from different regions worldwide. Springs from India and Taiwan show B isotope compositions around $40 \%$, indicating a major influence of seawater. Some saline springs (Nangqen Basin, China) and hot springs from Indonesia, China, and Japan are significantly depleted in ${ }^{11} \mathrm{~B}$ compared to present-day seawater, indicating a crustal origin. In China, two rivers, the Changjiang River and the Golmud River, range from -3 to $+9 \%$ and from -0.7 to $+9.6 \%$, respectively, and suggest that these variations result from $B$ isotope fractionation $[61,62]$ induced by a probable $B$ adsorption on clay minerals [63] that causes an enrichment in ${ }^{11} \mathrm{~B}$ in aqueous solutions [64]. $\delta^{11} \mathrm{~B}$ values of modern marine carbonates are about $22.1 \%$ [ [43]. Halite and borate from north German Basin were measured at 20.8 and $27.7 \%$, and marine evaporite borate and non-marine evaporite borates yielded $\delta^{11} \mathrm{~B}$ averages of $25 \pm 4 \%$ o and $-7 \pm 10 \%$, respectively [56]. Halite in the Qarhan area ranges from -1 to $6 \%$ and the modern brines from 2.9 to $7.5 \%$. The halite of the SR area ranges between 2.13 and $24.38 \%$ and modern brines from 17.31 to $26.31 \%$. Although XRD results identified no borate minerals the $\delta^{11} \mathrm{~B}$ of our halite samples are almost identical to those of the marine evaporite borate reported by Swihart et al. [56]. 


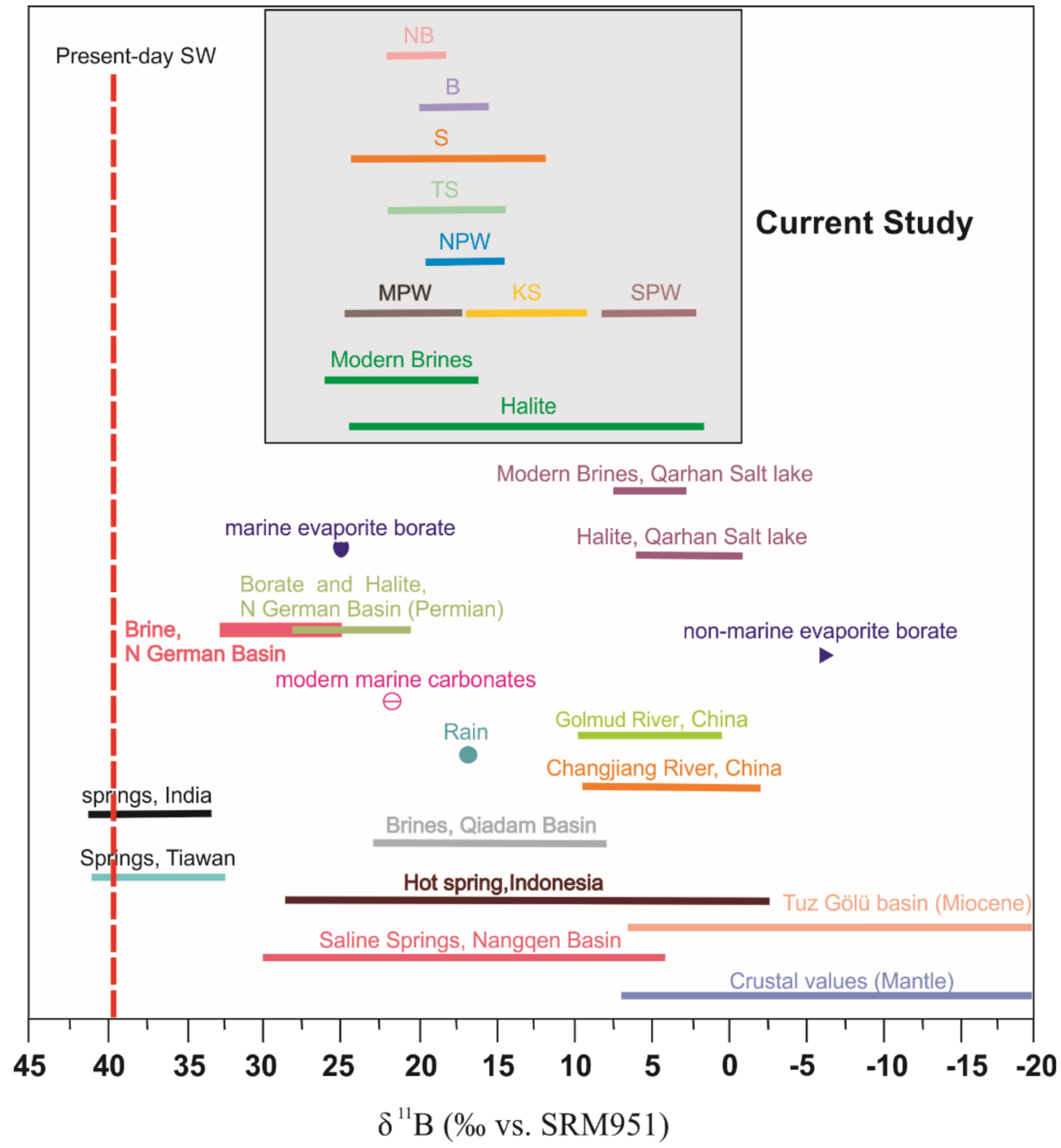

Figure 6. Comparison of the $\delta^{11} \mathrm{~B}$ values of Halite and Brines from the Salt Range formation with the $\delta^{11} \mathrm{~B}$ ranges of different materials. Data sources: crustal values from Chaussidon and Albarede (1992) [58]; Tuz Gölü Basin from Ercan at al. (2019) [65]; saline spring, China, hot springs, Indonesia, springs of Taiwan and India are from Han et al. (2018) [38]; Brines in Qiadam Basin, China from Xiao et al. (1999, 2000) [24,59]; River values from (Chetelat et al., 2009; Vengosh et al., 1995) [61,62], Rain water from Xiao et al. (1992) [65]; modern marine carbonate from Hemmin and Hanson (1991) [43]; Borate and halite, N German Basin from Kloppmann (2001) [66]; marine and non-marine evaporate borate from Swihart and Moore (1986) [55]; modern brine and halite, Qarhan salt lake from Fan et al. (2015) [5], whereas, brine and halite, Salt Range data is from the current study.

In this study, our data are in agreement with the regional plate tectonic history. About 560 Ma ago, during the late phase of the Rodinia tectonic regime, the new Pannotia supercontinent was formed. Soon after its creation, rifting caused its division into the Gondwana, Siberia Laurentia and Baltica continents, during the Neoproterozoic era [66]. Rifting and the drifting of these tectonic plates created, at their margins, oceanic to continental arc systems. The Salt Range formations deposited during this period under equatorial to subtropical conditions. Evaporites deposited from a warm temperature ocean under restricted shelf settings coupled with a regressive phase.

\section{Conclusions}

Here we studied boron and its isotopic geochemistry in halite and brines samples from the Salt Range Formation, Pakistan in order to better understand the boron global 
budget, to characterize its corresponding isotope fractionation and ultimately to constrain the prevailing paleoclimatic conditions during the mineral formation. Current results revealed that: (a) $\mathrm{B}^{3+}$ mainly originate from seawater and clay desorption, meanwhile fluid inclusions also play their role; (b) the formation of minerals is associated with a very small B isotope fractionation, consistent with previous studies. In terms of paleoclimatic conditions, present results confirm that seawater shifted from a dominantly $\mathrm{Na}-\mathrm{K}-\mathrm{Mg}$ $\mathrm{Ca}-\mathrm{Cl}$ (Ca-rich) brine towards a Na-K-Mg-Cl-SO ${ }_{4}\left(\mathrm{SO}_{4}\right.$-rich) type during the Phanerozoic $(\sim 550 \mathrm{Ma})$. Moreover, as the higher $\mathrm{B}$ concentrations in our halite samples correspond to the more positive $\delta^{11} \mathrm{~B}$, the $\mathrm{SR}$ area was characterized by a high evaporation rate, higher salinity and a drier paleoclimate. This approach coupling $\mathrm{B}$ elemental and $\delta^{11} \mathrm{~B}$ from halite rocks can easily be extended to other arid regions with the objectives of revealing their lake water paleosalinity and corresponding paleoclimate conditions, existed in the continents of Pannoti during Neoproterozoic time.

Author Contributions: Conceptualization, S.A.H.; methodology, S.A.H.; software Z.M., M.S.M. and A.A.; validation, F.-Q.H. and D.W.; formal analysis, S.A.H. and J.H.; investigation, S.A.H.; data curation, A.H.; writing — original draft preparation, S.A.H.; writing—review and editing, D.W. and F.-Q.H.; supervision, D.W. and F.-Q.H.; funding acquisition, F.-Q.H. All authors have read and agreed to the published version of the manuscript.

Funding: This scientific work was supported by the Qinghai Natural Science Foundation (grant No. 2019-ZJ-911).

Institutional Review Board Statement: Not applicable.

Informed Consent Statement: Not applicable.

Data Availability Statement: Not applicable.

Acknowledgments: We are thankful to Pakistan Mineral Development Corporation (PMDC) Pakistan for help during our field work. We aslo thank Shahid Naseem for insightful reviews and discussions, and the anonymous reviewers for their helpful comments.

Conflicts of Interest: The authors declare no conflict of interest.

\section{References}

1. Gou, G.-N.; Wang, Q.; Wyman, D.A.; Xia, X.-P.; Wei, G.-J.; Guo, H.-F. In situ boron isotopic analyses of tourmalines from Neogene magmatic rocks in the northern and southern margins of Tibet: Evidence for melting of continental crust and sediment recycling. Solid Earth Sci. 2017, 2, 43-54. [CrossRef]

2. Marschall, H.; Jiang, S.-Y. Tourmaline isotopes: No element left behind. Element 2011, 7, 313-319. [CrossRef]

3. Zhang, W.; Tan, H.; Zhang, Y.; Wei, H.; Dong, T. Boron geochemistry from some typical Tibetan hydrothermal systems: Origin and isotopic fractionation. Appl. Geochem. 2015, 63, 436-445. [CrossRef]

4. Xiao, J.; Xiao, Y.K.; Jin, Z.D.; He, M.Y.; Liu, C.Q. Boron isotope variations and its geochemical application in nature. Aust. J. Earth Sci. 2013, 60, 431-447. [CrossRef]

5. Fan, Q.; Ma, Y.; Cheng, H.; Wei, H.; Yuan, Q.; Qin, Z.; Shan, F. Boron occurrence in halite and boron isotope geochemistry of halite in the Qarhan Salt Lake, western China. Sediment. Geol. 2015, 322, 34-42. [CrossRef]

6. Tonarini, S.; D'Antonio, M.; Di Vito, M.A.; Orsi, G.; Carandente, A. Geochemical and B-Sr-Nd isotopic evidence for mingling and mixing processes in the magmatic system that fed the Astroni volcano (4.1-3.8 ka) within the Campi Flegrei caldera (southern Italy). Lithos 2009, 107, 135-151. [CrossRef]

7. Wei, H.-Z.; Jiang, S.-Y.; Tan, H.-B.; Zhang, W.-J.; Li, B.-K.; Yang, T.-L. Boron isotope geochemistry of salt sediments from the Dongtai salt lake in Qaidam Basin: Boron budget and sources. Chem. Geol. 2014, 380, 74-83. [CrossRef]

8. Yang, S.-Y.; Jiang, S.-Y. Chemical and boron isotopic composition of tourmaline in the Xiangshan volcanic-Intrusive complex, Southeast China: Evidence for boron mobilization and infiltration during magmatic-hydrothermal processes. Chem. Geol. 2012, 312, 177-189. [CrossRef]

9. Kloppmann, W.; Vengosh, A.; Guerrot, C.; Millot, R.; Pankratov, I. Isotope and ion selectivity in reverse osmosis desalination: Geochemical tracers for man-made freshwater. Environ. Sci. Technol. 2008, 42, 4723-4731. [CrossRef]

10. Muttik, N.; Kirsimäe, K.; Newsom, H.E.; Williams, L.B. Boron isotope composition of secondary smectite in suevites at the Ries crater, Germany: Boron fractionation in weathering and hydrothermal processes. Earth Planet. Sci. Lett. 2011, 310, $244-251$. [CrossRef] 
11. Liu, Y.; Liu, W.; Peng, Z.; Xiao, Y.; Wei, G.; Sun, W.; He, J.; Liu, G.; Chou, C.-L. Instability of seawater pH in the South China Sea during the mid-late Holocene: Evidence from boron isotopic composition of corals. Geochim. Cosmochim. Acta 2009, 73, 1264-1272. [CrossRef]

12. Xiao, J.; Xiao, Y.; Jin, Z.; Liu, C.; He, M. Boron isotopic compositions in growing corals from the South China Sea. J. Asian Earth Sci. 2013, 62, 561-567. [CrossRef]

13. Woodford, D.T.; Sisson, V.B.; Leeman, W.P. Boron metasomatism of the Alta stock contact aureole, Utah: Evidence from borates, mineral chemistry, and geochemistry. Am. Mineral. 2001, 86, 513-533. [CrossRef]

14. Deegan, F.M.; Troll, V.R.; Whitehouse, M.J.; Jolis, E.M.; Freda, C. Boron isotope fractionation in magma via crustal carbonate dissolution. Sci. Rep. 2016, 6, 30774. [CrossRef] [PubMed]

15. Nakano, T.; Nakamura, E. Boron isotope geochemistry of metasedimentary rocks and tourmalines in a subduction zone metamorphic suite. Phys. Earth Planet. Inter. 2001, 127, 233-252. [CrossRef]

16. Kasemann, S.A.; Meixner, A.; Erzinger, J.; Viramonte, J.G.; Alonso, R.N.; Franz, G. Boron isotope composition of geothermal fluids and borate minerals from salar deposits (central Andes/NW Argentina). J. S. Am. Earth Sci. 2004, 16, 685-697. [CrossRef]

17. Casanova, J.; Négrel, P.; Kloppmann, W.; Aranyossy, J. Origin of deep saline groundwaters in the Vienne granitic rocks (France): Constraints inferred from boron and strontium isotopes. Geofluids 2001, 1, 91-101. [CrossRef]

18. Paris, G.; Gaillardet, J.; Louvat, P. Geological evolution of seawater boron isotopic composition recorded in evaporites. Geology 2010, 38, 1036. [CrossRef]

19. Pearson, P.N.; Foster, G.L.; Wade, B.S. Atmospheric carbon dioxide through the Eocene-Oligocene climate transition. Nature 2009, 461, 1110. [CrossRef]

20. Du, Y.; Fan, Q.; Gao, D.; Wei, H.; Shan, F.; Li, B.; Zhang, X.; Yuan, Q.; Qin, Z.; Ren, Q. Evaluation of boron isotopes in halite as an indicator of the salinity of Qarhan Paleolake water in the Eastern Qaidam Basin, Western China. Geosci. Front. 2019, 10, 253-262. [CrossRef]

21. Liu, W.G.; Xiao, Y.K.; Peng, Z.C.; An, Z.S.; He, X.X. Boron concentration and isotopic composition of halite from experiments and salt lakes in the Qaidam Basin. Geochim. Cosmochim. Acta 2000, 64, 2177-2183. [CrossRef]

22. Zhang, X.; Ma, H.; Ma, Y.; Tang, Q.; Yuan, X. Origin of the late Cretaceous potash-bearing evaporites in the Vientiane Basin of Laos: $\delta 11 B$ evidence from borates. J. Asian Earth Sci. 2013, 62, 812-818. [CrossRef]

23. Vengosh, A.; Starinsky, A.; Kolodny, Y.; Chivas, A.R.; Raab, M. Boron isotope variations during fractional evaporation of sea water: New constraints on the marine vs. nonmarine debate. Geology 1992, 20, 799-802. [CrossRef]

24. Xiao, Y.; Shirodkar, P.; Liu, W.; Sun, D.; Wang, Y.; Jin, L. Boron isotopic geochemistry of salt lakes, Qaidam Basin, China. Adv. Nat. Sci. 1999, 917, 612-618.

25. Hussain, S.A.; Feng-Qing, H.; Yunqi, M.; Khan, H.; Jian, Y.; Hussain, G.; Widory, D. An overview of Pakistan rock salt resources and their chemical characterisation. Pak. J. Sci. Ind. Res. 2020.

26. Hussain, S.A.; Han, F.Q.; Han, J.; Khan, H.; Widory, D. Chlorine isotopes unravel conditions of formation of the Neoproterozoic rock salts from the Salt Range Formation, Pakistan. Can. J. Earth Sci. 2020. [CrossRef]

27. Hussain, S.A.; Han, F.-Q.; Han, W.; Rodríguez, A.; Han, J.-L.; Han, J.; Nian, X.-Q.; Yi, L.; Ma, Z.; Widory, D. Climate Change Impact on the Evolution of the Saline Lakes of the Soan-Sakaser Valley (Central Salt Range; Pakistan): Evidences from Hydrochemistry and Water $(\delta \mathrm{D}, \delta 18 \mathrm{O})$ and Chlorine $(\delta 37 \mathrm{Cl})$ Stable Isotopes. Water 2019, 11, 912. [CrossRef]

28. Powell, C.M.; Roots, S.; Veevers, J. Pre-breakup continental extension in East Gondwanaland and the early opening of the eastern Indian Ocean. Tectonophysics 1988, 155, 261-283. [CrossRef]

29. Gee, E.; Gee, D. Overview of the geology and structure of the Salt Range, with observations on related areas of northern Pakistan. Geol. Soc. Am. Spec. Pap. 1989, 232, 95-112.

30. Ghazi, S.; Ali, S.H.; Sahraeyan, M.; Hanif, T. An overview of tectonosedimentary framework of the Salt Range, northwestern Himalayan fold and thrust belt, Pakistan. Arab. J. Geosci. 2015, 8, 1635-1651. [CrossRef]

31. Grelaud, S.; Sassi, W.; de Lamotte, D.F.; Jaswal, T.; Roure, F. Kinematics of eastern Salt Range and South Potwar basin (Pakistan): A new scenario. Mar. Pet. Geol. 2002, 19, 1127-1139. [CrossRef]

32. Richards, L.; King, R.; Collins, A.; Sayab, M.; Khan, M.; Haneef, M.; Morley, C.; Warren, J. Macrostructures vs microstructures in evaporite detachments: An example from the Salt Range, Pakistan. J. Asian Earth Sci. 2015, 113, 922-934. [CrossRef]

33. Le Fort, P. Himalayas: The collided range. Present knowledge of the continental arc. Am. J. Sci. 1975, 275, 1-44.

34. Krishnan, M. Salt tectonics in the Punjab salt range, Pakistan. Geol. Soc. Am. Bull. 1966, 77, 115-122. [CrossRef]

35. Schröder, S.; Schreiber, B.C.; Amthor, J.E.; Matter, A. A depositional model for the terminal Neoproterozoic-Early Cambrian Ara Group evaporites in south Oman. Sedimentology 2003, 50, 879-898. [CrossRef]

36. Fatmi, A.N. Lithostratigraphic units of the Kohat-Potwar province, Indus basin, Pakistan. Mem. Geol. Surv. Pak. 1974, 10, 1-80.

37. Sameeni, S.J. The Salt Range. In PaleoParks: The Protection and Conservation of Fossil Sites Worldwide; Département des Sciences de la Terre, Université de Bretagne Occidentale: Brest, French, 2009; pp. 65-73.

38. Han, J.-L.; Han, F.-Q.; Hussain, S.-A.; Liu, W.-Y.; Nian, X.-Q.; Mao, Q.-F. Origin of Boron and Brine Evolution in Saline Springs in the Nangqen Basin, Southern Tibetan Plateau. Geofluids 2018. [CrossRef]

39. Han, J.; Jiang, H.; Xu, J.; Hussain, S.A.; Yuan, X.; Qin, X. Hydraulic connection affects uranium distribution in the Gas Hure salt lake, Qaidam Basin, China. Environ. Sci. Pollut. Res. 2018, 25, 4881-4895. [CrossRef] 
40. Han, J.; Xu, J.; Hussain, S.A.; Jiang, H.; Ma, Y.; Xu, K.; Ma, H. Origin of the Boron in the Gas Hure Salt Lake of the Northwestern Qaidam Basin, China: Evidence from Hydrochemistry and Boron Isotopes. Acta Geol. Sin. Engl. Ed. 2019, 4. [CrossRef]

41. Xiao, Y.-K.; Beary, E.; Fassett, J. An improved method for the high-precision isotopic measurement of boron by thermal ionization mass spectrometry. Int. J. Mass Spectrom. Ion Process. 1988, 85, 203-213. [CrossRef]

42. Ying-Kai, X.; Bu-Yong, L.; Wei-Guo, L.; Yun, X.; George, H.S. Ion Exchange Extraction of Boron from Aqueous Fluids by Amber-lite IRA 743 Resin. Chin. J. Chem. 2003, 21, 1073-1079.

43. Hemming, N.G.; Hanson, G.N. Boron isotopic composition and concentration in modern marine carbonates. Geochim. Cosmochim. Acta 1992, 56, 537-543. [CrossRef]

44. Farooqui, M.A.; Umar, M.; Sabir, M.A.; Pervez, R.; Jalees, T. Geochemical attributes of late Neoproterozoic Salt Range Formation, Pakistan: Constraints on provenance, paleoclimate, depositional and tectonic settings. Geosci. J. 2019, 23, 201-218. [CrossRef]

45. Vengosh, A.; Chivas, A.R.; Mcculloch, M.T.; Starinsky, A.; Kolodny, Y. Boron isotope geochemistry of Australian salt lakes. Geochim. Cosmochim. Acta 1991, 55, 2591-2606. [CrossRef]

46. Williams, L.B.; Hervig, R.L.; Hutcheon, I. Boron isotope geochemistry during diagenesis: Part II, Applications to organic-rich sediments. Geochim. Cosmochim. Acta 2001, 65, 1783-1794. [CrossRef]

47. Chao, H.; You, C. Distribution of B, $\mathrm{Cl}$ and their isotopes in pore waters separated from gas hydrate potential areas, offshore southwestern Taiwan. Terr. Atmos. Ocean. Sci. 2006, 17, 961. [CrossRef]

48. Warren, J.K. Depositional Chemistry and Hydrology. In Evaporites; Springer: Berlin/Heidelberg, Germany, 2016 ; pp. 85-205.

49. Boschetti, T.; Toscani, L.; Salvioli Mariani, E. Boron isotope geochemistry of NaN arom gas hydrate potential areas, offshore southwestern Taiwan. n. on provenanceoredeep basin: Other pieces of the sedimentary basin puzzle. Geofluids 2015, 15, 546-562. [CrossRef]

50. Millot, R.; Petelet-Giraud, E.; Guerrot, C.; Négrel, P. Multi-isotopic composition $(\delta 7 \mathrm{Li}-\delta 11 \mathrm{~B}-\delta \mathrm{D}-\delta 18 \mathrm{O})$ of rainwaters in France: Origin and spatio-temporal characterization. Appl. Geochem. 2010, 25, 1510-1524. [CrossRef]

51. Spivack, A.; Palmer, M.; Edmond, J. The sedimentary cycle of the boron isotopes. Geochim. Cosmochim. Acta 1987, 51, 1939-1949. [CrossRef]

52. Lowenstein, T.K.; Timofeeff, M.N.; Brennan, S.T.; Hardie, L.A.; Demicco, R.V. Oscillations in Phanerozoic seawater chemistry: Evidence from fluid inclusions. Science 2001, 294, 1086-1088. [CrossRef]

53. Deyhle, A.; Kopf, A.J.; Aloisi, G. Boron and boron isotopes as tracers for diagenetic reactions and depth of mobilization, using muds and authigenic carbonates from eastern Mediterranean mud volcanoes. Geol. Soc. Lond. Spec. Publ. 2003, 216, 491-503. [CrossRef]

54. You, C.-F.; Spivack, A.; Gieskes, J.; Martin, J.; Davisson, M. Boron contents and isotopic compositions in pore waters: A new approach to determine temperature induced artifacts-Geochemical implications. Mar. Geol. 1996, 129, 351-361. [CrossRef]

55. Baker, D.M.; Lillie, R.J.; Yeats, R.S.; Johnson, G.D.; Yousuf, M.; Zamin, A.S.H. Development of the Himalayan frontal thrust zone: Salt Range, Pakistan. Geology 1988, 16, 3-7. [CrossRef]

56. Swihart, G.H.; Moore, P.B.; Callis, E.L. Boron isotopic composition of marine and nonmarine evaporite borates. Geochim. Cosmochim. Acta 1986, 50, 1297-1301. [CrossRef]

57. Song, L.Y. Indoor evaporation experiment on water of South China Sea. Acta Geosicientia Sin. 1994, 1, 157-167, (In Chinese with English Abstract).

58. Chaussidon, M.; Albarède, F. Secular boron isotope variations in the continental crust: An ion microprobe study. Earth Planet. Sci. Lett. 1992, 108, 229-241. [CrossRef]

59. Xiao, Y.; Wei, H.; Yin, D. Progress on Isotopic Geochemistry of Boron and Chlorine in Salt Lakes. J. Salt Lake Res. $2000,8,30-40$.

60. Qi, H.; Wang, Y.; Xiao, Y.; Sun, D.; Jin, L.; Tang, Y. The preliminary study on the boron isotope of Chinese salt lakes. Chin. Sci. Bull. 1993, 38, 634 .

61. Chetelat, B.; Liu, C.Q.; Gaillardet, J.; Wang, Q.L.; Zhao, Z.Q.; Liang, C.S.; Xiao, Y.K. Boron isotopes geochemistry of the Changjiang basin rivers. Geochim. Cosmochim. Acta 2009, 73, 6084-6097. [CrossRef]

62. Vengosh, A.; Chivas, A.R.; Starinsky, A.; Kolodny, Y.; Zhang, B.; Zhang, P. Chemical and boron isotope compositions of non-marine brines from the Qaidam Basin, Qinghai, China. Chem. Geol. 1995, 120, 135-154. [CrossRef]

63. Schwarcz, H.P.; Agyei, E.K.; Mcmullen, C.C. Boron isotopic fractionation during clay adsorption from sea-water. Earth Planet. Sci. Lett. 1969, 6, 1-5. [CrossRef]

64. Palmer, M.R.; Spivack, A.J.; Edmond, J.M. Temperature and $\mathrm{pH}$ controls over isotopic fractionation during adsorption of boron on marine clay. Geochim. Cosmochim. Acta 1987, 51, 2319-2323. [CrossRef]

65. Ercan, H.Ü.; Karakaya, M.Ç.; Bozdağ, A.; Karakaya, N.; Delikan, A. Origin and evolution of halite based on stable isotopes ( $837 \mathrm{Cl}$, $\delta 81 \mathrm{Br}, \delta 11 \mathrm{~B}$ and $\delta 7 \mathrm{Li}$ ) and trace elements in Tuz Gölü Basin, Turkey. Appl. Geochem. 2019, 105, 17-30. [CrossRef]

66. Scotese, C.R. Late Proterozoic plate tectonics and palaeogeography: A tale of two supercontinents, Rodinia and Pannotia. Geol. Soc. Lond. Spec. Publ. 2009, 326, 67-83. [CrossRef] 